\title{
Synergistic effect of Hydnophytum formicarum tuber and Vatica diospyroides Symington cotyledon extracts with ampicillin on pathogenic bacteria
}

\author{
Kanokrat Keawchai ${ }^{1}$, Parinuch Chumkaew ${ }^{1}$ (D) , Patima Permpoonpattana ${ }^{2}$ (D), Theera Srisawat ${ }^{2 *}$ (D) \\ ${ }^{1}$ Faculty of Science and Industrial Technology, Prince of Songkla University, Surat Thani Campus, Surat Thani, Thailand. \\ ${ }^{2}$ Faculty of Innovative Agriculture and Fisheries, Prince of Songkla University, Surat Thani Campus, Surat Thani, Thailand.
}

\section{ARTICLE INFO \\ Article history: \\ Received on: September 17, 2021 \\ Accepted on: November 13, 2021 \\ Available Online: February 15, 2022}

Key words:

Checkerboard, flow cytometry, Hydnophytum formicarum, synergistic, Vatica diospyroides

\begin{abstract}
This research aimed to study the potential synergistic effect of Hydnophytum formicarum tuber and Vatica diospyroides Symington cotyledon extracts combined with ampicillin on Staphylococcus aureus ATCC 25923 and Escherichia coli ATTC 25922. The antibacterial efficacy was assessed using agar well diffusion, minimum inhibitory concentration (MIC), fractional inhibitory concentration index (FICI), and a flow cytometry assay. The results indicate synergy in antibacterial activity of combined $V$. diospyroides cotyledon extract with ampicillin, which was more effective than $H$. formicarum tuber extract against both bacterial species (clear zone sizes $49.33 \pm 0.58$ and $30.67 \pm 1.15 \mathrm{~mm}$ for $S$. aureus and $E$. coli, respectively). The MIC values for the combination against these bacteria were 1,000:3.125 and 500:3.125 $\mu \mathrm{g} / \mathrm{ml}$, respectively. The FICI values of the combination were 1.06 and 0.375 , demonstrating independent and synergistic effects, respectively. The results of flow cytometry indicated that the combined extract-antibiotic inhibited bacteria by acting on cell membrane and by granularity disruptions, with the cell membrane representing the primary target followed by lost granularity. Vatica diospyroides cotyledon extract may increase the efficacy of ampicillin and reduce 8-fold the required antibiotic concentration. These results support a drug discovery program assessing $V$. diospyroides combined with antibiotics as therapy against resistant bacteria.
\end{abstract}

\section{INTRODUCTION}

At present, infectious diseases cause about one-third of morbidity and deaths of people worldwide. While antibiotics are essential in treating bacterial infections, their overuse or misuse selects for resistant bacterial strains, and these are the main causes of failure in the treatment of diseases [1]. Therefore, it is necessary to search for new approaches to control resistant bacteria. Phytotherapy has played a significant role in the prevention and treatment, with few side effects. However, only a few medicinal plants have evolved into actual drugs because of the lack of sufficient efficacy [2]. One possible approach is to combine medicinal plant products with antibiotics for enhanced antibacterial activity against the

*Corresponding Author

Theera Srisawat, Faculty of Innovative Agriculture and Fisheries, Prince of Songkla University, Surat Thani Campus, Surat Thani, Thailand. E-mail: theera.s@psu.ac.th resistant pathogen $[3,4]$. The plants used in this current study were Hydnophytum formicarum Jack and Vatica diospyroides Symington, which have been reported to possess antibacterial activities $[5,6]$.

This study was, therefore, conducted to assess the possibility of beneficial interactions (synergy) of $H$. formicarum tuber or $V$. diospyroides cotyledon extracts when combined with ampicillin against Staphylococcus aureus ATCC 25923 and Escherichia coli ATTC 25922. This is the first reported study on the synergistic effects of these plants with antibiotics, and the initial results we report are very encouraging.

\section{MATERIALS AND METHODS}

\subsection{Preparation of Plant Extracts and Bacterial Strains}

The crude extracts of $H$. formicarum tuber and $V$. diospyroides Symington cotyledon was extracted by maceration in $95 \%$ ethyl alcohol and in absolute acetone, respectively [6]. Briefly, the plant 
Keawchai et al.: Biological sciences: Synergistic effect of Hydnophytum formicarum tuber and Vatica diospyroides Symington cotyledon extracts with ampicillin on pathogenic bacteria 2022;10(02):6-11

materials $(270 \mathrm{~g})$ were extracted for 5 days before being filtered and evaporated until the dry residues were obtained. The collected crude extracts were stored in cool and dark conditions. All extracts were redissolved in dimethyl sulfoxide (DMSO) for preparing final stock solutions (40 mg/ml). The bacteria used in this study were $S$. aureus ATCC 25923 and E. coli ATCC 25922, which were maintained at the Scientific Laboratory and Equipment Center, Prince of Songkla University, Surat Thani Campus, Thailand. The bacteria were inoculated into Nutrient Broth prior to incubation until the mid-log phase (approximately $10^{8} \mathrm{CFU} / \mathrm{ml}$ ).

\subsection{Agar Well Diffusion}

Antibacterial activities of $H$. formicarum tuber and $V$. diospyroides cotyledon extracts and ampicillin alone and combinations of $H$. formicarum and $V$. diospyroides extracts with ampicillin were determined with the agar well diffusion method. Each plate with 25 $\mathrm{ml}$ of Mueller-Hinton agar was inoculated using a cotton swab with a mid-log phase culture of each bacterial strain. The wells $(6 \mathrm{~mm}$ diameter) were punched in the agar using a cork borer. Then, each well received $50 \mu \mathrm{l}$ of $H$. formicarum $(2,000 \mu \mathrm{g} /$ well $), V$. diospyroides $(2,000 \mu \mathrm{g} /$ well), or ampicillin (concentration from 12.5 to $50 \mu \mathrm{g} /$ well) alone, both $H$. formicarum $(1,000 \mu \mathrm{g} /$ well) and ampicillin (12.5 to 50 $\mu \mathrm{g} /$ well $)$, or both $V$. diospyroides $(1,000 \mu \mathrm{g} /$ well $)$ and ampicillin $(12.5$ to $50 \mu \mathrm{g} / \mathrm{well})$. DMSO at $10 \%$ was used as a negative control. The plates were incubated at $37^{\circ} \mathrm{C}$ for 24 hours. The antibacterial activity was assessed by measuring the inhibition zone diameter $(\mathrm{mm})$ in three replicates, reported as mean \pm standard deviation (SD). The plant extract was chosen for further experiment based on the efficacy of clear zone interest.

\subsection{Evaluation of Minimum Inhibitory Concentration (MIC)}

MICs of $V$. diospyroides cotyledon extract and ampicillin alone were determined by resazurin-based 96-well microdilution as shown in Figure 1. The inoculated plate was incubated at $37^{\circ} \mathrm{C}$ for 24 hours. After incubation, $10 \mu \mathrm{l}$ of $0.015 \%$ resazurin was added to each well and further incubated for $2-4$ hours at $37^{\circ} \mathrm{C}$. MIC was defined as the lowest concentration of the tested compound at which the resazurin color did not change from blue to pink [7].

\subsection{Determination of Synergistic Effect by Checkerboard Assay}

A series of two-fold dilutions of the $V$. diospyroides from 31.25 to $2,000 \mu \mathrm{g} / \mathrm{ml}$ and ampicillin from 1.56 to $100 \mu \mathrm{g} / \mathrm{ml}$ were prepared for every combination tested, and $70 \mu 1$ aliquots of each component were placed into the wells of the 96-well plate. An aliquot of bacterial suspension $(50 \mu \mathrm{l})$ was added to each well. Negative and positive controls were as described above. The plates were then incubated and tested with $0.015 \%$ resazurin. The interaction between $V$. diospyroides and ampicillin was assessed using the Fractional Inhibitory Concentration Index (FICI) calculated as follows:

\section{FICI=FIC of $V$.diospyroides + FIC of ampicillin}

when FIC of $V$.diospyroides $=\frac{\text { MIC of combined } V \text {.diospyroides }}{\text { MIC of individual } V \text {.diospyroides }}$

and FIC of ampicillin $=\frac{\text { MIC of combined ampicillin }}{\text { MIC of individual ampicillin }}$

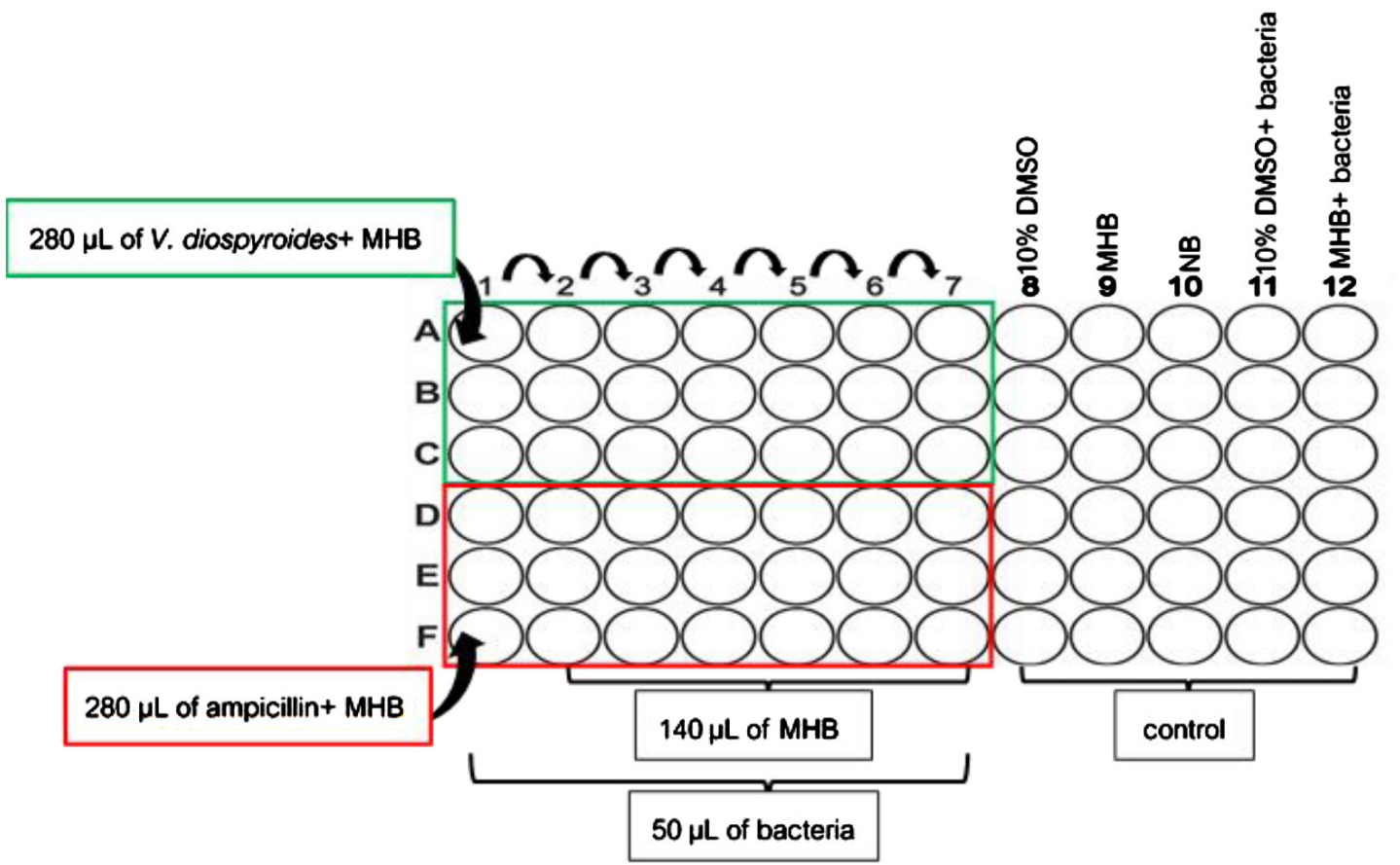

Figure 1: The 96-well plate used for MIC testing. An aliquot (280 ml) of a mixed solution of Mueller-Hinton Broth (MHB) and 2 -fold $V$. diospyroides concentration $(2,000 \mu \mathrm{g} / \mathrm{ml})$ was added to the first well, and ampicillin $(100 \mu \mathrm{g} / \mathrm{ml}) \mathrm{was}$ mixed in as well. Wells $2-7$ had $140 \mu \mathrm{l}$ MHB. To prepare $V$. diospyroides concentrations $(31.25-2,000 \mu \mathrm{g} / \mathrm{ml})$ or ampicillin concentrations $(1.56-100 \mu \mathrm{g} / \mathrm{ml}), 140 \mu \mathrm{l}$ aliquot was pipetted from the first well and added to the next well for two-fold serial microdilution in the 96 -well plate. $50 \mu \mathrm{l}$ of bacterial suspension was added to each well. 
Table 1: Antibacterial activities of ampicillin combined with $H$. formicarum tuber extract or with $V$. diospyroides Symington cotyledon extract against S. aureus ATCC 25923 and E. coli ATCC 25922, as determined by agar well diffusion.

\begin{tabular}{|c|c|c|c|}
\hline \multirow{2}{*}{\multicolumn{2}{|c|}{ Extract concentration $(\mu \mathrm{g} /$ well $)$}} & \multicolumn{2}{|c|}{ Zone of inhibition $($ mean \pm SD $)(\mathbf{m m})$} \\
\hline & & \multirow{2}{*}{$\begin{array}{l}\text { S. aureus ATCC } 25923 \\
\text { one }\end{array}$} & \multirow{2}{*}{ E. coli ATCC 25922} \\
\hline \multirow{4}{*}{ Ampicillin } & Alone & & \\
\hline & 50 & $46.67 \pm 0.58^{\mathrm{bc}}$ & $26.67 \pm 0.58^{\mathrm{b}}$ \\
\hline & 25 & $44.67 \pm 0.58^{\mathrm{d}}$ & $24.33 \pm 0.58^{\mathrm{c}}$ \\
\hline & 12.5 & $43.67 \pm 0.58^{d}$ & $21.67 \pm 0.58^{\mathrm{d}}$ \\
\hline H. formicarum & 1,000 & $9.00 \pm 0.00^{\mathrm{h}}$ & 0 \\
\hline \multirow[t]{2}{*}{ V. diospyroides } & 1,000 & $16.33 \pm 0.58^{\mathrm{g}}$ & 0 \\
\hline & \multicolumn{2}{|c|}{ Combination } & \\
\hline \multirow[t]{3}{*}{ Ampicillin: H. formicarum } & $50: 1,000$ & $38.33 \pm 1.15^{\mathrm{e}}$ & $27.33 \pm 0.58^{\mathrm{b}}$ \\
\hline & $25: 1,000$ & $37.67 \pm 0.58^{\mathrm{e}}$ & $25.00 \pm 1.00^{\mathrm{c}}$ \\
\hline & $12.5: 1,000$ & $36.33 \pm 0.58^{\mathrm{f}}$ & $20.67 \pm 1.52^{\mathrm{d}}$ \\
\hline \multirow[t]{3}{*}{ Ampicillin: $V$. diospyroides } & $50: 1,000$ & $49.33 \pm 0.58^{\mathrm{a}}$ & $30.67 \pm 1.15^{\mathrm{a}}$ \\
\hline & $25: 1,000$ & $47.67 \pm 0.58^{\mathrm{b}}$ & $26.67 \pm 1.15^{\mathrm{b}}$ \\
\hline & $12.5: 1,000$ & $46.33 \pm 0.58^{\mathrm{c}}$ & $22.00 \pm 1.00^{\mathrm{d}}$ \\
\hline $10 \%$ DMSO & & 0 & 0 \\
\hline
\end{tabular}

Values shown are the mean of inhibition zone diameter $(\mathrm{mm}) \pm \mathrm{SD}$ from three replicates. Statistically significant differences between means are shown by different superscripts, based on DMRT $(p=0.05)$.

Table 2: The MIC and FICI values of ampicillin combined with $V$. diospyroides extract against $S$. aureus ATCC 25923 and E. coli ATCC 25922, compared to the treatments done singly.

\begin{tabular}{cccccc} 
Bacterial species & \multicolumn{2}{c}{ Individual } & \multicolumn{2}{c}{ Combination } & FICI \\
& Ampicillin & V. diospyroides & Ampicillin & V. diospyroides & \\
S. aureus & 50 & 1,000 & 3.125 & 1,000 & 1.06 (indifferent) \\
E. coli & 25 & 2,000 & 3.125 & 500 & 0.375 (synergistic) \\
\hline
\end{tabular}

The results were labeled as synergistic (FICI $<0.5)$, partially synergistic $(0.5<$ FICI $<1)$, additive $($ FICI $=1)$, indifferent $(1<$ FICI $<4)$, or antagonistic $($ FICI $>4)$ [8]. The bacteria chosen for the synergistic result were selected for the next experiment.

\subsection{Estimation of Cell Membrane Permeability and Granular Integrity of $\boldsymbol{E}$. coli by Flow Cytometry}

The evaluation of bacterial responses to combinations of $V$. diospyroides with ampicillin against $E$. coli was based on flow cytometry. The membrane integrity and the retained granularity of $E$. coli were estimated following the method described by Musimun et al. [6]. Briefly, propidium iodide (PI) staining was used, and then the cytometric profiles (fluorescence intensity and side scatter) were assessed in scatter plots. The varied experiment parameters were $V$. diospyroides, ampicillin, and their blends with varying concentrations, as follows: $250 \mu \mathrm{g} / \mathrm{ml}$ of $V$. diospyroides: $1.56 \mu \mathrm{g} / \mathrm{ml}$ of ampicillin (0.5 MIC), $500 \mu \mathrm{g} / \mathrm{ml}$ of $V$. diospyroides: $3.125 \mu \mathrm{g} / \mathrm{ml}$ of ampicillin (MIC), and 1,000 $\mu \mathrm{g} / \mathrm{ml}$ of $V$. diospyroides: $6.25 \mu \mathrm{g} / \mathrm{ml}$ of ampicillin (2 MIC).

The flow cytometry was performed with a BD FACSCalibur flow cytometer (Becton Dickinson Biosciences (BDB), San Jose, CA) equipped with a $448 \mathrm{~nm}$ air-cooled argon laser. A total of 10,000 events per sample were acquired and analyzed with CellQuest software (BDB). Red fluorescence of PI-stained cells was detected in the fluorescence pulse height (FL2-H) detector. Both FL2-H and side scatter (SSC) signals were monitored as logarithmic signals. The populations of viable cells, membrane-damaged cells, injured cells, and dead cells in each sample were analyzed using WinMDI version 2.9 software (Scripps Institute, La Jolla, CA).

\section{RESULTS}

This study evaluated the antibacterial potential of $H$. formicarum and $V$. diospyroides extracts singly and when combined with ampicillin against $S$. aureus ATCC 25923 and E. coli ATCC 25922. The results revealed that the plants combined with ampicillin showed different antibacterial activities against these bacterial strains. By the size of the clear zone, the highest antibacterial activity was observed for $V$. diospyroides combined with ampicillin against both types of bacteria. As shown in Table 1, the largest values of inhibition zone were $49.33 \pm 0.58$ and $30.67 \pm 1.15 \mathrm{~mm}$, respectively.

The checkerboard assay was used to evaluate the potential synergy of $V$. diospyroides with ampicillin against both types of bacteria. The interactions were assessed from FICI values. Vatica diospyroides combined with ampicillin had an indifferent effect on $S$. aureus ATCC 25923 with FICI $=1.06$, while it exhibited a synergistic effect against $E$. coli ATCC 25922 with $\mathrm{FICI}=0.375$ (Table 2 and Fig. 2). Interestingly, the synergy could reduce 8-fold the MIC of ampicillin from that when it is used alone. 


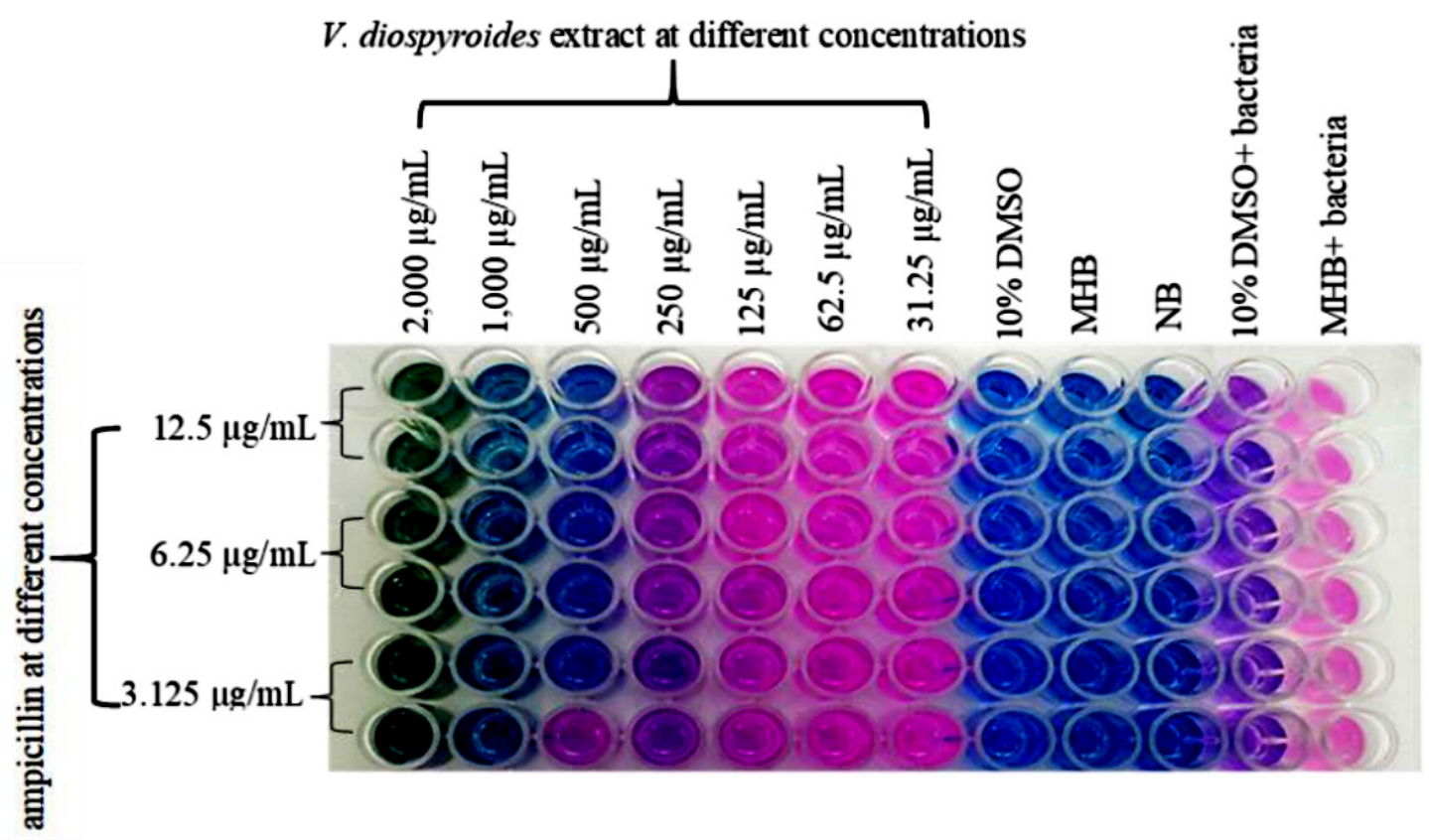

(a) S. aureus

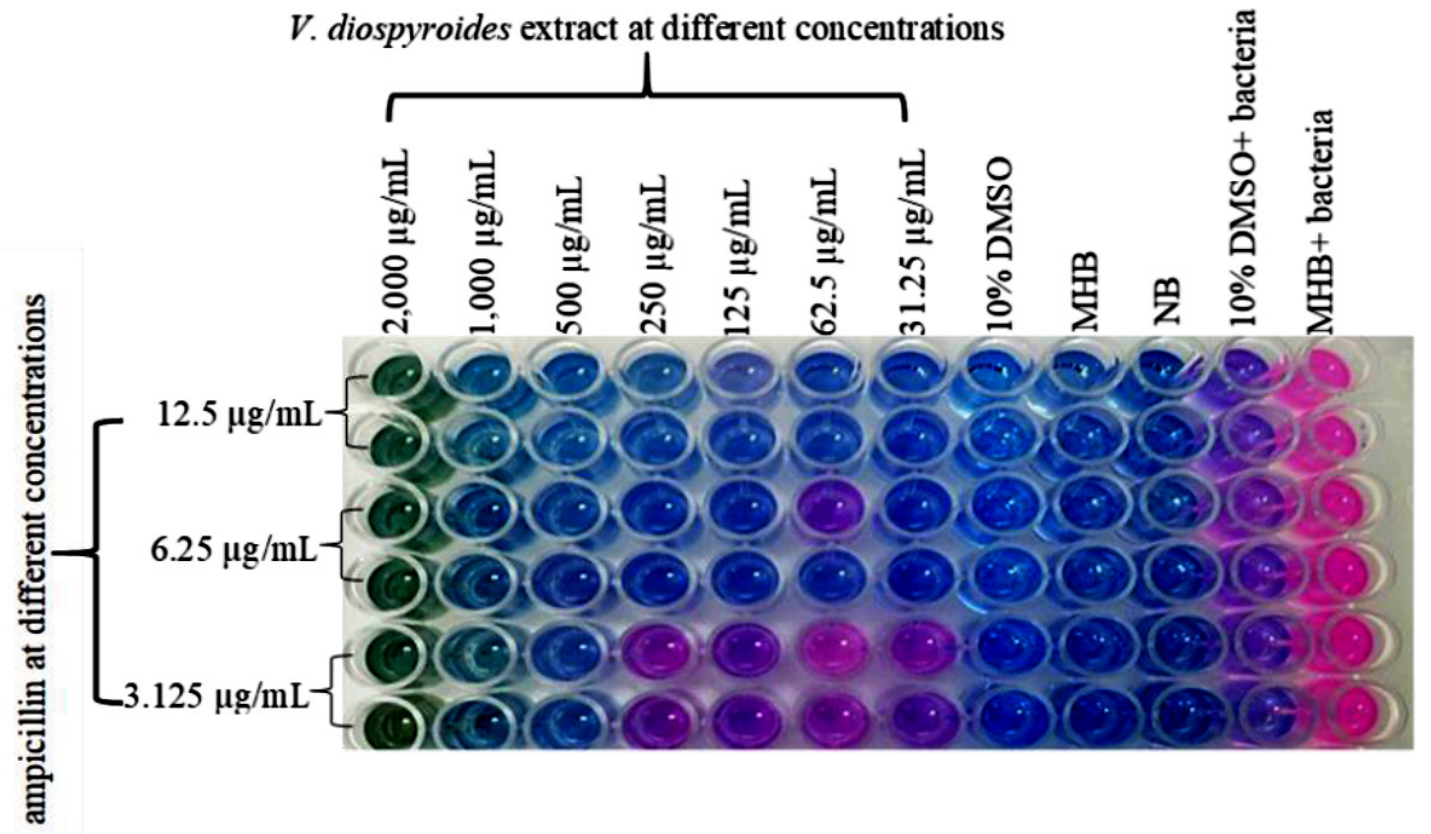

(b) E. coli

Figure 2: Synergistic effect of ampicillin combined with $V$. diospyroides extract against $S$. aureus (a) and $E$. coli (b) tested by the checkerboard assay. 


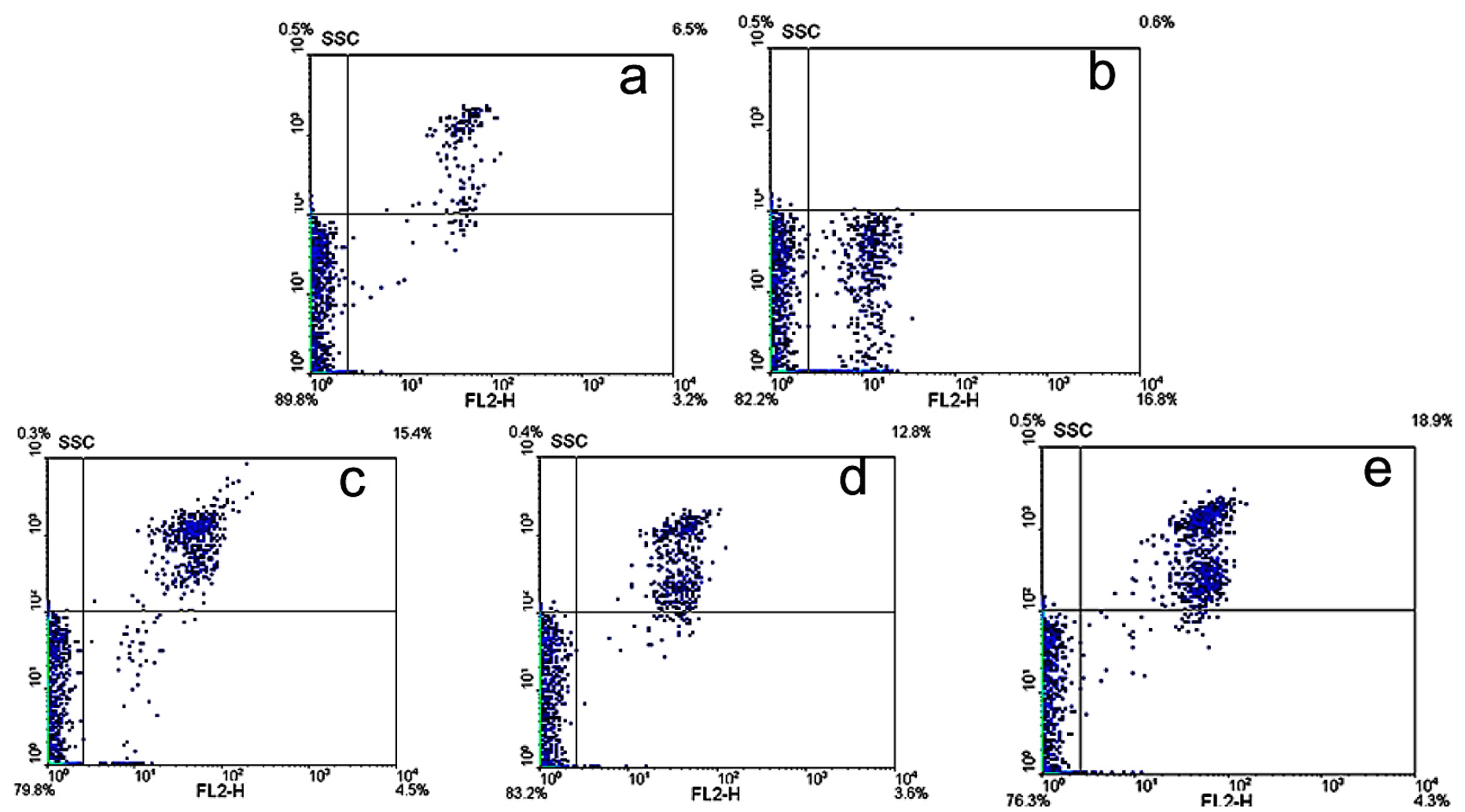

Figure 3: Flow cytometry scatter plots for $E$. coli ATCC 25922 treated with $1,000 \mu \mathrm{g} / \mathrm{ml}$ of $V$. diospyroides (a), $50 \mu \mathrm{g} / \mathrm{ml}$ of ampicillin (b), $250 \mu \mathrm{g} / \mathrm{ml}$ of $V$. diospyroides: $1.56 \mu \mathrm{g} / \mathrm{ml}$ of ampicillin (c), $500 \mu \mathrm{g} / \mathrm{ml}$ of $V$. diospyroides: $3.125 \mu \mathrm{g} / \mathrm{ml}$ of ampicillin (d), and $1,000 \mu \mathrm{g} / \mathrm{ml}$ of $V$. diospyroides:6.25 $\mu \mathrm{g} / \mathrm{ml}$ of ampicillin (e) for 12 hours. *The dividing lines separate viable cells (lower left), membrane-damaged cells (lower right), injured cells (upper left), and dead cells (upper right).

The synergy of $V$. diospyroides with ampicillin was evaluated at three concentrations by monitoring the death pattern of $E$. coli ATCC 25922 after 12 hours of incubation. The response pattern of this bacteria to $V$. diospyroides alone was the loss of membrane permeability and subsequent loss of granularity of cells $(3.2 \%$ of membrane-damaged cells and $6.5 \%$ of dead cells). In contrast, the response pattern of $E$. coli ATCC 25922 to ampicillin was only by the loss of membrane integrity with $16.8 \%$ of responded cells (Fig. 3). Interestingly, the response pattern of this bacteria to synergistic treatment was similar to $V$. diospyroides extract alone, but it shows a higher proportion of cell death $(12.8 \%-18.9 \%)$ than that of the extract or ampicillin alone.

\section{DISCUSSION}

In the present study, the efficacy of $V$. diospyroides extract in combination with ampicillin was found to possess more effect than $H$. formicarum extract on $S$. aureus ATCC 25923 and E. coli ATCC 25922. In our previous report, terpenoids, anthraquinones, and saponins were found to be the major constituents in cotyledon extract of $V$. diospyroides [9]. Terpenoids have strong antibacterial activity against bacteria, especially Gram-negative bacteria [10]. On the other hand, saponins have antimicrobial activity against Gram-positive and Gram-negative bacteria by disrupting cell wall and by membrane damage [11]. Although antibacterial activity has been reported by many authors for anthraquinone derivatives, most anthraquinones are only active against Gram-positive bacteria [12]. Ampicillin is a beta-lactam antibiotic that inhibits Gram-positive and some Gram- negative bacteria [13]. Therefore, in the synergistic results, most of the antibacterial effect by combination of $V$. diospyroides with ampicillin might be attributed to terpenoids in the plant extract.

For synergistic interaction, resembling those obtained as antibacterial results, the synergistic effect of $V$. diospyroides with ampicillin against $E$. coli ATCC 25922 was less than 0.5 . This value indicates the ideal efficacy of a combination of both substances. A similar pattern was previously reported by Shah et al. [14] who reported that the interaction of Ocimum sanctum extract with ampicillin was synergistic against $E$. coli with a FICI below 0.5 . The extract of $O$. sanctum contained terpenoids and saponins, resembling, in this sense, the extract from $V$. diospyroides.

For flow cytometric analysis, the highest proportion of membranedamaged $E$. coli was found when treated with ampicillin alone. The amino group in ampicillin inhibits cell wall biosynthesis [13]. Interestingly, the response to the mixture was similar to $V$. diospyroides, but it is leading eventually mostly to death. While $V$. diospyroides fruit extracts have antibacterial activity only against the Gram-positive bacteria [6], the mode of action of this extract when combined with ampicillin was mostly by inhibiting Gram-negative bacteria, with an 8-fold reduction in the concentration of the antibiotic.

\section{CONCLUSION}

In conclusion, the results of this study indicate improved antibacterial efficacy of $V$. diospyroides extract when mixed with ampicillin against $E$. coli ATCC 25922, such that it could reduce 
Keawchai et al.: Biological sciences: Synergistic effect of Hydnophytum formicarum tuber and Vatica diospyroides Symington cotyledon 11 extracts with ampicillin on pathogenic bacteria 2022;10(02):6-11

the 8 -fold use of the antibiotic. The flow cytometry results confirm that the combination treatment with extract-antibiotic inhibited E. coli both by acting on the cell membrane and by granularity disruption. Thus, this synergy could support novel alternative treatments of infectious diseases, mitigating problems with emerging drug resistance.

\section{AUTHOR CONTRIBUTIONS}

TS designed the experiment and contributed to the implementation of the research, to the analysis of the results, and to the writing of the manuscript. KK and PP performed the aseptic technique experiment. PC prepared crude extractions.

\section{FUNDING}

This work was supported by a scholarship from Graduate School, Prince of Songkla University, and Prince of Songkla University, Surat Thani Campus.

\section{DATA AVAILABILITY}

All data generated and analyzed are included within this research article.

\section{CONFLICTS OF INTEREST}

The authors declared no conflicts of interest.

\section{ETHICAL APPROVAL}

Not applicable.

\section{REFERENCES}

1. World Health Organization. Global report on antimicrobial resistance. 2015. Available via http://apps.who.int/iris/ bitstream/10665/112642/1/9789241564748_eng.pdf?ua=1 (Accessed 15 November 2019).

2. Rasoanaivo P, Wright CW, Willcox ML, Gilbert B. Whole plant extracts versus single compounds for the treatment of malaria: synergy and positive interactions. Malaria J 2011;10(SUPPL. 1):S4.

3. Chung P, Navaratnam P, Chung L. Synergistic antimicrobial activity between pentacyclic triterpenoids and antibiotics against Staphylococcus aureus strains. Ann Clin Microbiol Antimicrob 2011;10:1-6.

4. Masoumian M, Zandi M. Antimicrobial activity of some medicinal plant extracts against multidrug resistant bacteria. Zahedan J Res Med Sci 2017;19(11):e10080.
5. Andriani Y, Mohamad H, Nur M, Kassim I, Rosnan ND, Syamsumir DF. Evaluation on Hydnophytum formicarum tuber from Setiu Wetland (Malaysia) and Muara Rupit (Indonesia) for antibacterial and antioxidant activities and anti-cancer potency against MCF-7 and HeLa cells. J Appl Pharm Sci 2017;7(9):30-7.

6. Musimun C, Chuysongmuang M, Permpoonpattana P, Chumkaew P, Sontikul Y, Ummarat N, et al. FACS analysis of bacterial responses to extracts of Vatica diospyroides fruit show dose and time dependent induction pattern. Walailak J Sci Technol 2017;14(11):883-91.

7. Elshikh M, Ahmed S, Funston S, Dunlop P, McGaw M, Marchant $\mathrm{R}$, et al. Resazurin-based 96-well plate microdilution method for the determination of minimum inhibitory concentration of biosurfactants. Biotechnol Lett 2016;38:1015-9.

8. Mohammadi M, Hatef K, Koroush S, Setareh S, Fatemeh, S, Somayeh $\mathrm{D}$, et al. Synergistic effect of colistin and rifampin against multidrug resistant: a systematic review and meta-analysis. Open Microbiol J 2017;11(1):63-71.

9. Srisawat T, Chumkaew P, Heed-Chim W, Chumkaew P, Sukpondma Y, Kanokwiroon K. Phytochemical screening and cytotoxicity of crude extract of Vatica diospyroides Symington type LS. Trop J Pharm Res 2013;12:71-6.

10. Guimarães AC, Meireles LM, Lemos MF, Guimarães MCC, Endringer DC, Fronza M, et al. Antibacterial activity of terpenes and terpenoids present in essential oils. Molecules 2019;24(13):2471.

11. Monte J, Abreu AC, Borges A, Simões LC, Simões M. Antimicrobial activity of selected phytochemicals against Escherichia coli and Staphylococcus aureus and their biofilms. Pathogens 2014;3:473-98.

12. Kemegne GA, Mkounga P, Ngang JJE, Kamdem SLS, Nkengfack AE. Antimicrobial structure activity relationship of five anthraquinones of emodine type isolated from Vismia laurentii. BMC Microbiol 2017;17:41-9.

13. Akinyele $\mathrm{T}$, Igbinosa $\mathrm{E}$, Akinpelu $\mathrm{D}$, Okoh $\mathrm{A}$. In vitro assessment of the synergism between extracts of Cocos nucifera husk and some standard antibiotics. Asian Pac J Trop Biomed 2017;7(4):306-13.

14. Shah F, Hasan Z, Zaidi KU. Evaluation of phytoconstituent and synergistic antibacterial activity of Ocimum sanctum extract against some Gram-positive and Gram-negative species. Biosci Biotechnol Res Commun 2016;9(4):856-64.

How to cite this article:

Keawchai K, Chumkaew P, Permpoonpattana P, Srisawat T. Biological sciences: Synergistic effect of Hydnophytum formicarum tuber and Vatica diospyroides Symington cotyledon extracts with ampicillin on pathogenic bacteria. J Appl Biol Biotech 2022; 10(02):6-11. 